\title{
A BATTERY ENERGY STORAGE SYSTEM BASED ON A MULTILEVEL CASCADE PWM CONVERTER
}

\author{
Hirofumi Akagi and Laxman Maharjan \\ Department of Electrical and Electronic Engineering \\ Tokyo Institute of Technology, Tokyo, Japan \\ akagi@ee.titech.ac.jp
}

\begin{abstract}
This paper describes a 6.6-kV battery energy storage system based on a multilevel cascade PWM (pulsewidth-modulation) converter with star configuration. It discusses design concepts with and without a linefrequency transformer for grid connection. The control system consists of state-of-charge (SOC)-balancing control and fault-tolerant control. The former is indispensable for effective utilization of battery energy while the latter is required for maintaining continuous operation during a converter-cell or battery-unit fault. A $200-\mathrm{V}, 10-\mathrm{kW}, 3.6-$ kWh laboratory system combining a three-phase cascade PWM converter with nine nickel-metal-hydride (NiMH) battery units is designed, constructed, and tested to verify the validity and effectiveness of the proposed control system.
\end{abstract}

Keywords - Battery energy storage system (BESS), cascade converters, fault-tolerant control, state-of-charge (SOC) balancing.

\section{INTRODUCTION}

\section{A. Background}

The use of renewable energy resources such as wind power and solar power is penetrating more quickly than ever [1]. For example, over the past ten years, the global wind power capacity has grown by an average rate of over $30 \%$ annually, reaching more than $120 \mathrm{GW}$ by the end of 2008 [2]. However, renewable energy resources are "intermittent" in nature. Their power varies minute by minute under the influence of meteorological fluctuations. Therefore, a large amount of renewable energy may produce a bad effect on power system stability in terms of voltage and frequency [3]. Energy storage systems [4] are indispensable for successfully integrating renewable energy sources into power systems.

Significant advances in battery technologies have spurred interests in energy storage systems based on batteries. Walker described a 10-MW 40-MWh battery energy storage system combining an 18-pulse voltage-source converter with leadacid batteries [5]. The dc voltage ranged from 1750 to $2860 \mathrm{~V}$. It used complicated zigzag transformers in order to synthesize a staircase voltage waveform. Miller et al. [6] presented a 5-MVA 2.5-MWh battery energy storage system using leadacid batteries with a dc-voltage range from 660 to $900 \mathrm{~V}$. It was based on a pair of six-pulse converters, forming a 12pulse converter, and three 12-pulse converters were paralleled to achieve the required power rating. The transformers used

Manuscript received October 6, 2009; revised November 26, 2009. Accepted by recommendation of the Associate Editors E. H. Watanabe and J. A. Pomilio. in [5] and [6] would be expensive, bulky, lossy, and prone to failure. Modern multilevel converters such as diode-clamped, flying capacitor, and cascade converters are preferable to traditional transformer-based multipulse converters [7]- [12].

Although multilevel cascade converters have been primarily investigated for STATCOMs (static synchronous compensators) and motor drives [13]- [18], their prominent structure makes them suitable for energy storage systems using electric double-layer capacitors (EDLCs) and batteries [19]- [21]. However, when the cascade converters are used for battery energy storage systems, state-ofcharge (SOC) balancing of multiple battery units would be indispensable for achieving stable operation. Besides, fault tolerance would be desirable for maintaining continuous operation during the occurrence of a converter-cell or battery-unit fault.

\section{B. SOC Balancing of Battery Units}

The SOC of a battery unit is defined by its available capacity expressed as a percentage of the maximum available capacity. A battery management system (BMS) plays an important part in estimating the SOC, which is often called the "fuel gauge" function. Due to asymmetric battery units, unequal convertercell losses, and so on, SOC imbalance may occur among multiple battery units in a battery energy storage system based on a cascade converter. This may bring a reduction in total available capacity to the battery units, and may also cause overcharge/overdischarge of a particular battery unit. Therefore, SOC balancing is essential.

Tolbert et al. [22] described a multilevel cascade converter using battery units for a motor drive. They discussed a switching-pattern-swapping scheme for achieving SOC balancing of the multiple battery units, but did not provide experimental verification. The scheme may be confined to a multilevel cascade converter based on stair-case modulation (SCM). Moreover, it assumed that the battery units were identical and that their initial SOC values were balanced.

\section{Fault Tolerance}

Fault tolerance is desirable so as to improve both reliability and availability of an energy storage system [23], [24]. Fortunately, an energy storage system based on a cascade converter has the potential of maintaining continuous operation at the rated or reduced voltage and power during a converter-cell or battery-unit fault. The fault-tolerant operation can be achieved;

1. by providing a redundant converter cell in each phase, and bypassing the faulty converter cell as well as two healthy converter cells in the other two phases, or

2 . by bypassing the faulty converter cell only without 
providing redundant converter cells.

Song et al. [25] discussed a fault-tolerant control for a STATCOM based on a cascade converter, which belongs to the first category. During normal operation with a cascade number $N+1$, the cascade converter has a voltage level of $2 N+3$. When a converter cell is out of order, the voltage level is reduced to $2 N+1$. This approach is suitable for critical applications, because it can ride through a fault in at least one converter cell at the rated voltage and power. However, it adds cost and reduces efficiency.

Wei et al. [26] and Rodriguez et al. [27] described faulttolerant controls belonging to the second category for cascadeconverter-based motor drives. They bypassed a faultyconverter cell and executed the "neutral shift" so as to produce a maximum achievable three-phase balanced lineto-line voltage at the ac side of the cascade converter. The neutral shift implies shifting the floating (ungrounded) neutral point of the star-configured cascade converter away from the neutral point of the source or the ac mains. Lezana et al. [28] controlled the dc-link voltages as well as executing the neutral shift to keep a cascade-converter-based motor drive operated at the rated voltage and power during a converter-cell fault. However, the authors of most literatures have devoted themselves to theoretical analysis and/or computer simulation.

This paper describes a design concept of the $6.6-\mathrm{kV}$ battery energy storage system based on a multilevel cascade pulsewidth-modulation (PWM) converter with star configuration. The paper discusses SOC-balancing control of multiple battery units for effective utilization of battery energy. It also discusses the fault-tolerant control for maintaining continuous operation at the rated voltage and power during a converter-cell or battery-unit fault, thus improving reliability. Experimental results obtained from a 200-V, 10-kW, 3.6-kWh laboratory system justify the proposed control methods.

\section{DESIGN CONCEPT OF THE 6.6-KV SYSTEM}

\section{A. Transformer-Based System}

Figure 1 shows a feasible circuit configuration of the 6.6$\mathrm{kV}$ energy storage system using nickel-metal-hydride (NiMH) battery units. It is based on a cascade PWM converter. Careful assignment of a cascade number and an operating voltage range of each battery unit are of vital importance in the system design. A transformer is used to realize an energy storage system with a suitable cascade number and a reasonable dc voltage. Note that it is a simple step-down transformer that is easily available from the market at reasonable cost, compared to a multi-winding transformer in a conventional multipulse converter [5].

The so-called "asymmetrical cascade converter," characterized by battery units with different dc voltages in multiple H-bridge converter cells, might be attractive in reducing harmonic voltage/current and switching power loss [29]. However, the authors of this paper prefer the symmetrical cascade converter to the asymmetrical one, because the use of the battery units and converter cells with the same voltage, current, and capacity ratings brings the "modularity" to the energy storage system.

A fully-charged NiMH battery cell measures $1.4 \mathrm{~V}$ and

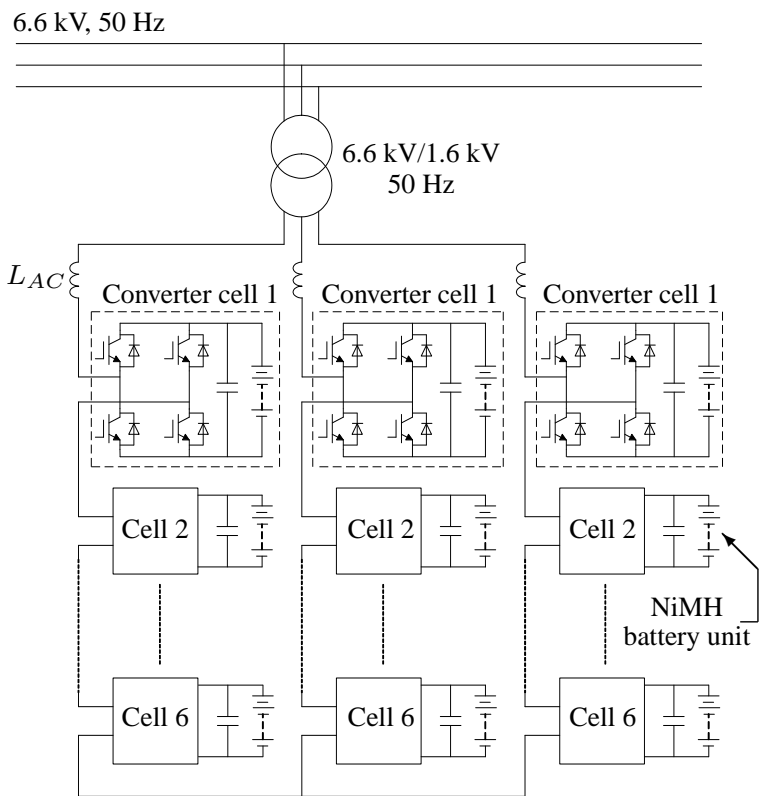

Fig. 1. Feasible circuit configuration of the $6.6-\mathrm{kV}$ transformer-based battery energy storage system based on combination of a cascade PWM converter with a cascade number $N=6$, and $18 \mathrm{NiMH}$ battery units with a nominal voltage of $288 \mathrm{~V}$.

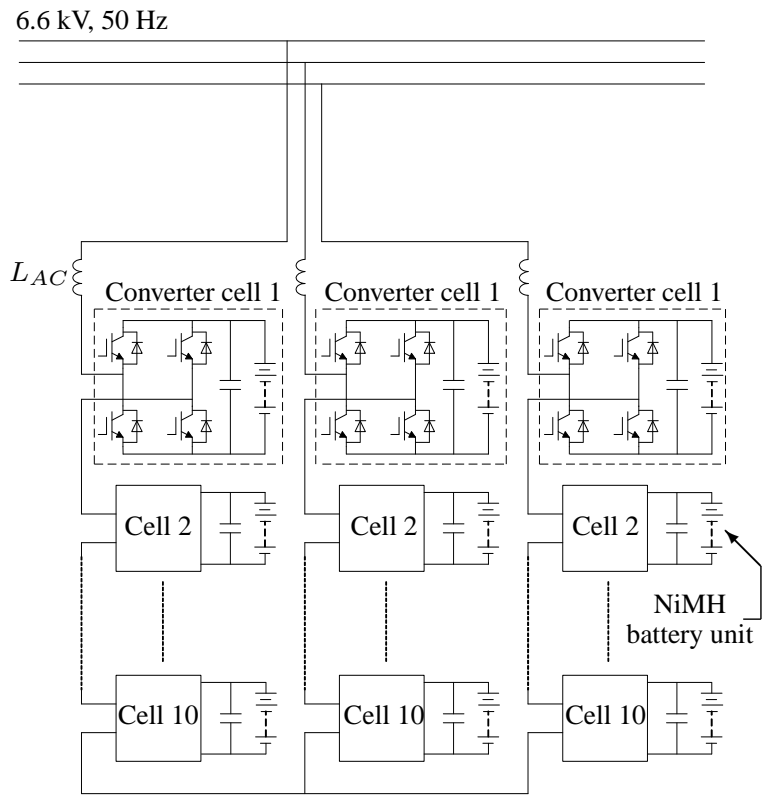

Fig. 2. Feasible circuit configuration of the $6.6-\mathrm{kV}$ transformerless battery energy storage system based on combination of a cascade PWM converter with a cascade number $N=10$, and $30 \mathrm{NiMH}$ battery units with a nominal voltage of $660 \mathrm{~V}$.

supplies a nominal voltage of $1.2 \mathrm{~V}$ during discharge, down to about $1.0-1.1 \mathrm{~V}$ [30]. The nominal voltage of a battery unit in the $6.6-\mathrm{kV}$ system may be $288 \mathrm{~V}(=1.2 \mathrm{~V} \times 240$ cells $)$. An operating voltage of the battery unit may range from $270 \mathrm{~V}$ to $330 \mathrm{~V}$. Note that NiMH battery units with nominal voltage at 200-300 V have already been used in hybrid electric vehicles (HEVs) [31]. If the cascade number is $N=6$, a $6.6 \mathrm{kV} / 1.6 \mathrm{kV}$ transformer is required to connect the energy storage system 
to the $6.6-\mathrm{kV}$ grid. Lithium (Li)-ion battery units with the same nominal voltage as $288 \mathrm{~V}(=3.6 \mathrm{~V} \times 80$ cells $)$ are also applicable to the system.

General-purpose IGBTs rated at $600 \mathrm{~V}$ and $200 \mathrm{~A}$ can be used as power switching devices. The 18 converter cells are controlled by the so-called "phase-shifted unipolar sinusoidal PWM" [32], [33]. Even though the PWM carrier frequency is set as low as $1 \mathrm{kHz}$, the equivalent carrier frequency is as high as $12 \mathrm{kHz}(=2 \times 6$ cells $\times 1 \mathrm{kHz})$. Moreover, setting such a low carrier frequency as $1 \mathrm{kHz}$ brings a significant reduction in switching power loss to each converter cell. The ac voltage results in a 13-level waveform in line-to-neutral and a 25-level waveform in line-to-line, thus significantly improving the total harmonic distortion (THD) in both voltage and current.

\section{B. Transformerless System}

A transformer-based system seems more practical at present. Nevertheless, a transformerless system may also be viable in the next 5-10 years, in which the cascade number and the dc-link voltage would be higher than those in the transformer-based system. Their optimization would be required to address communication [34] and reliability issues as well as cost and life issues of battery units. It has been shown that battery life tends to degrade almost exponentially as the number of series-connected cells in a battery unit increases. Although cell balancing [35]- [37] can enhance its life, it is accompanied by an additional cost of cell-balancing hardware. Note that this paper does not address cell balancing in a battery unit whereas it discusses SOC balancing among the multiple battery units.

Figure 2 shows a feasible circuit configuration of the 6.6$\mathrm{kV}$ transformerless battery energy storage system based on a combination of a three-phase cascade PWM converter with a cascade number $N=10$ and $30 \mathrm{NiMH}$ battery units. The nominal voltage of a battery unit is $660 \mathrm{~V}(=1.2 \mathrm{~V} \times$ 550 cells). An operating voltage of the battery unit may range from $605 \mathrm{~V}$ to $770 \mathrm{~V}$. With nominal cell voltage at $3.6 \mathrm{~V}, \mathrm{Li}$-ion battery unit can reach the same dc voltage with a relatively lower number of battery cells in series and therefore, may be more suitable for the $6.6-\mathrm{kV}$ transformerless system. General-purpose IGBTs rated at $1.2-\mathrm{kV}$ and $200-\mathrm{A}$ may be used as power switching devices. Using phase-shifted unipolar sinusoidal PWM with a carrier frequency of $1 \mathrm{kHz}$ would make the equivalent carrier frequency as high as $20 \mathrm{kHz}$, and the ac voltage results in a 21 -level waveform in line-to-neutral.

The major advantage of the transformerless system over the transformer-based one may be elimination of bulky and heavy line-frequency transformer. This, however, is at the cost of losing galvanic isolation. An energy density of the latest batteries is so high that the consequences of failure can be very serious. Adequate measures should be taken to isolate the battery system from the grid in the event of a grounding fault. Further research and development especially in the field of batteries would be needed in order to realize the transformerless system.

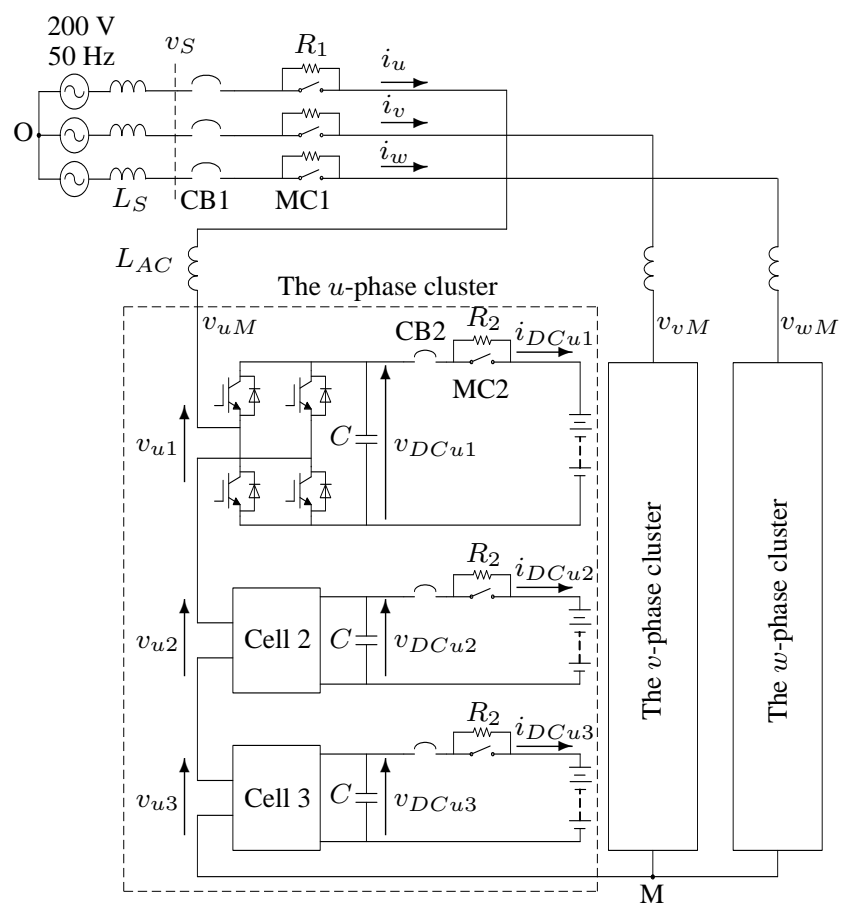

Fig. 3. Experimental system configuration of the $200-\mathrm{V}, 10-\mathrm{kW}$, 3.6-kWh down-scaled energy storage system based on combination of a three-phase cascade PWM converter with a cascade number $N=3$, and nine NiMH battery units with a nominal voltage of $72 \mathrm{~V}$.

TABLE I

Circuit parameters of the experimental battery energy storage system

\begin{tabular}{l|c|r}
\hline \hline Nominal line-to-line rms voltage & $V_{S}$ & $200 \mathrm{~V}$ \\
\hline Power rating & $P$ & $10 \mathrm{~kW}$ \\
\hline Cascade number & $N$ & 3 \\
\hline AC inductor & $L_{A C}$ & $1.2 \mathrm{mH}(10 \%)$ \\
\hline Background system inductance & $L_{S}$ & $48 \mu \mathrm{H}(0.4 \%)$ \\
\hline Starting Resistors & $R_{1}, R_{2}$ & $10 \Omega, 20 \Omega$ \\
\hline Nominal DC voltage & $V_{D C}$ & $72 \mathrm{~V}$ \\
\hline DC capacitor & $C$ & $16.4 \mathrm{mF}$ \\
\hline Unit capacitance constant & $H$ & $38 \mathrm{~ms} \mathrm{at} 72 \mathrm{~V}$ \\
\hline NiMH battery unit & & $72 \mathrm{~V}$ and $5.5 \mathrm{Ah}$ \\
\hline PWM carrier frequency & & $800 \mathrm{~Hz}$ \\
\hline Equivalent carrier frequency & & $4.8 \mathrm{kHz}$ \\
\hline
\end{tabular}

\section{THE 200-V, 10-KW, 3.6-KWH EXPERIMENTAL SYSTEM}

\section{A. System Configuration}

Figure 3 shows the system configuration of an experimental battery energy storage system rated at $200 \mathrm{~V}, 10 \mathrm{~kW}$ and $3.6 \mathrm{kWh}$. Table I summarizes the circuit parameters. The experimental system is star-configured and has a cascade number $N=3$. Each of the nine converter cells is equipped with a NiMH battery unit at its de side. Each battery unit is rated at $72 \mathrm{~V}$ and $5.5 \mathrm{Ah}$, consisting of series connection of 60 battery cells, where the dc voltage ranges from $66 \mathrm{~V}$ to $84 \mathrm{~V}$. The total rated energy capacity is $13 \mathrm{MJ}$ or $3.6 \mathrm{kWh}$ $(=72 \mathrm{~V} \times 5.5 \mathrm{Ah} \times 9)$.

Figure 4 shows the control system of the $200-\mathrm{V}$ system. 


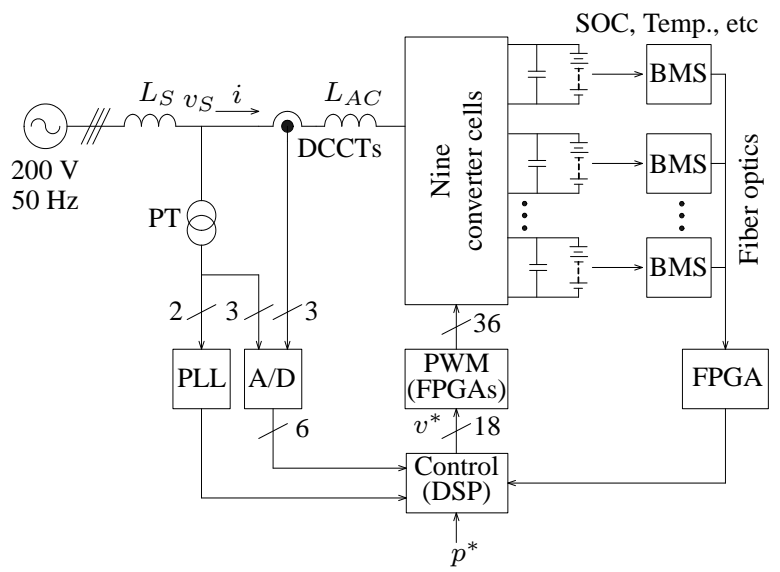

Fig. 4. Control system for the battery energy storage system.

This is based on a fully-digital controller using a digital signal processor (DSP) and multiple field programmable gate arrays (FPGAs). Each battery unit is equipped with the BMS that provides the functions of monitoring and controlling the respective battery unit to protect it against abnormal conditions. The BMS also provides the function of SOC estimation [38], the detail of which is beyond the scope of this paper.

The nine H-bridge converter cells are controlled by phaseshifted unipolar sinusoidal PWM with a carrier frequency of $800 \mathrm{~Hz}$. The resulting line-to-neutral voltage is a seven-level waveform with an equivalent carrier frequency of $4.8 \mathrm{kHz}$ (= $2 \times 3$ cells $\times 800 \mathrm{~Hz}$ ). The active-power command is denoted as $p^{*}$ in Figure 4.

\section{B. Overview of the Control System}

Figure 5 shows the control block diagram of the energy storage system. The whole control system is divided into the following three sub-controls:

1. active-power control

2. SOC-balancing control

3. fault-tolerant control.

The active-power control is based on decoupled current control, which is the same in control method and parameters as that presented in [39].

The SOC-balancing control is divided into;

- clustered SOC-balancing control, and

- individual SOC-balancing control.

The aim of the clustered SOC-balancing control is to keep the mean SOC value of a cluster or phase equal to the mean SOC value of the three clusters. This means,

$$
\left[\begin{array}{c}
\Delta \mathrm{SOC}_{u} \\
\Delta \mathrm{SOC}_{v} \\
\Delta \mathrm{SOC}_{w}
\end{array}\right]=\left[\begin{array}{c}
\mathrm{SOC}-\mathrm{SOC}_{u} \\
\mathrm{SOC}-\mathrm{SOC}_{v} \\
\mathrm{SOC}-\mathrm{SOC}_{w}
\end{array}\right] \approx 0
$$

where

$$
\mathrm{SOC}=\frac{1}{3}\left(\mathrm{SOC}_{u}+\mathrm{SOC}_{v}+\mathrm{SOC}_{w}\right)
$$

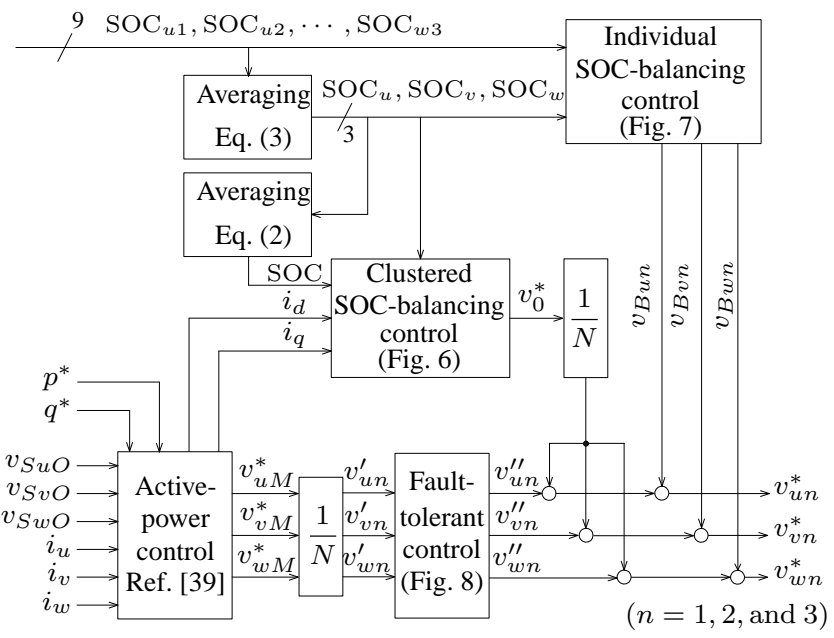

Fig. 5. Control block diagram for the $200-\mathrm{V}$ system with a cascade number $N=3$.

$$
\left[\begin{array}{c}
\mathrm{SOC}_{u} \\
\mathrm{SOC}_{v} \\
\mathrm{SOC}_{w}
\end{array}\right]=\frac{1}{3}\left[\begin{array}{c}
\mathrm{SOC}_{u 1}+\mathrm{SOC}_{u 2}+\mathrm{SOC}_{u 3} \\
\mathrm{SOC}_{v 1}+\mathrm{SOC}_{v 2}+\mathrm{SOC}_{v 3} \\
\mathrm{SOC}_{w 1}+\mathrm{SOC}_{w 2}+\mathrm{SOC}_{w 3}
\end{array}\right]
$$

Similarly, the aim of the individual SOC-balancing control is to keep each of the three SOC values in a cluster equal to the mean SOC value of the corresponding cluster. That means, taking $u$-phase as an example,

$$
\Delta \mathrm{SOC}_{u n}=\mathrm{SOC}_{u}-\mathrm{SOC}_{u n} \approx 0 .
$$

Both the clustered and individual balancing controls are based on feedback control.

The fault-tolerant control is based on feedforward control and achieves the following two functions during a convertercell or battery-unit fault;

- one is to maintain continuous operation at the rated voltage and power, producing a three-phase balanced line-to-line ac voltage, and

- the other is to achieve SOC balancing of all the $3 N-1$ healthy battery units.

Both SOC-balancing control and fault-tolerant control are explained in the following sections.

\section{SOC-BALANCING CONTROL}

\section{A. Clustered SOC-Balancing Control}

The basic idea of clustered SOC-balancing control is to achieve neutral shift by adding a line-frequency zero-sequence voltage $v_{0}$ to the three-phase ac voltages $v_{u M}, v_{v M}$, and $v_{w M}$ of the cascade converter. This allows each of the three clusters to draw or release an unequal active power without drawing negative-sequence current. Note that the idea of zerosequence voltage injection itself is not new. For example, Betz et al. [40] investigated the injection of zero-sequence voltage/current for capacitor-voltage balancing in a cascadeconverter-based STATCOM, intended for negative-sequence compensation of three-phase line currents.

Figure 6 shows the block diagram of clustered SOC-balancing control. The SOC 


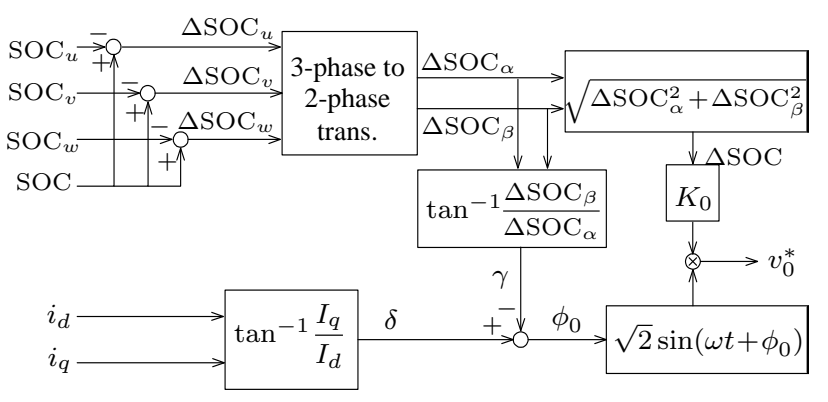

Fig. 6. Clustered SOC-balancing control based on zero-sequence voltage injection.

differences $\left(\Delta \mathrm{SOC}_{u}, \Delta \mathrm{SOC}_{v}\right.$, and $\left.\Delta \mathrm{SOC}_{w}\right)$ correspond to an amount of active power to be drawn or released by each of the three clusters to maintain SOC balancing among the clusters. Let $\triangle \mathrm{SOC}$ and $\gamma$ be defined as

$$
\begin{aligned}
& \Delta \mathrm{SOC}=\sqrt{\Delta \mathrm{SOC}_{\alpha}^{2}+\Delta \mathrm{SOC}_{\beta}^{2}} \\
&=\sqrt{\Delta \mathrm{SOC}_{u}^{2}+\Delta \mathrm{SOC}_{v}^{2}+\Delta \mathrm{SOC}_{w}^{2}}, \\
& \gamma= \begin{cases}\tan ^{-1} \frac{\Delta \mathrm{SOC}_{\beta}}{\Delta \mathrm{SOC}_{\alpha}} & \text { if } \Delta \mathrm{SOC}_{\alpha} \neq 0 \\
\frac{\pi}{2} & \text { if } \Delta \mathrm{SOC}_{\alpha}=0 \text { and } \Delta \mathrm{SOC}_{\beta}>0 \\
-\frac{\pi}{2} & \text { if } \Delta \mathrm{SOC}_{\alpha}=0 \text { and } \Delta \mathrm{SOC}_{\beta}<0 .\end{cases}
\end{aligned}
$$

Here, $\triangle \mathrm{SOC}$ is a parameter representing a degree of SOC imbalance among the three clusters, while $\gamma$ is a parameter associated with a distribution of SOC imbalance among the three clusters in terms of a phase angle on the $\alpha-\beta$ axes.

The zero-sequence-voltage reference is determined as

$$
v_{0}^{*}=\sqrt{2} \cdot K_{0} \cdot \Delta \mathrm{SOC} \cdot \sin \left(\omega t+\phi_{0}\right),
$$

where $K_{0}$ is a proportional gain, and $\phi_{0}$ is given by

$$
\begin{aligned}
\phi_{0}= & \delta-\gamma \\
\delta & =\left\{\begin{array}{l}
\tan ^{-1} \frac{I_{q}}{I_{d}} \quad \text { if } I_{d} \neq 0 \\
\left.\frac{\pi}{2} \quad \text { if } I_{d}=0 \text { and } I_{q}>0\right) \\
\left.-\frac{\pi}{2} \quad \text { if } I_{d}=0 \text { and } I_{q}<0\right)
\end{array}\right.
\end{aligned}
$$

where $I_{d}$ and $I_{q}$ are equal to the $d$-axis component $\left(i_{d}\right)$ and the $q$-axis component $\left(i_{q}\right)$ of current $i$ in a sinusoidal steadystate condition. The zero-sequence-voltage injection given by (7) balances the mean SOC values of the three clusters without producing any effect on the overall three-phase power transfer, because the sum of $u-, v$-, and $w$-phase active powers due to zero-sequence voltage injection is zero.

\section{B. Individual SOC-Balancing Control}

Figure 7 shows the individual SOC-balancing control paying attention to the $n^{t h}$-converter cells of the three clusters. Taking the $u$-phase as an example rewrites (4) as follow:

$$
\Delta \mathrm{SOC}_{u n}=\mathrm{SOC}_{u}-\mathrm{SOC}_{u n},
$$

where $n=1,2$, and 3 . The difference $\Delta \mathrm{SOC}_{u n}$ is minimized by appropriately charging or discharging the respective battery

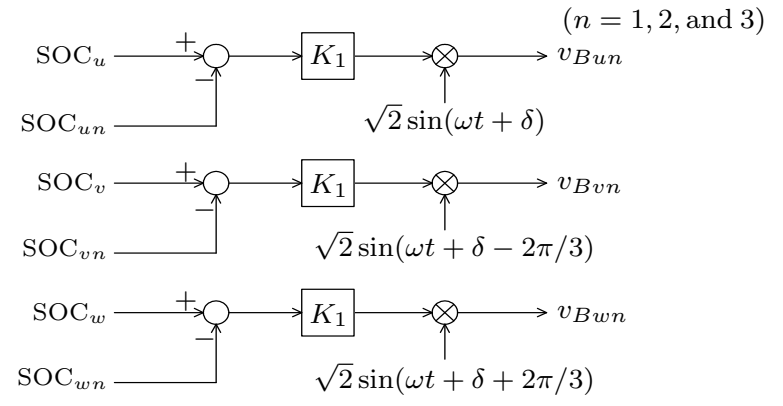

Fig. 7. Individual SOC-balancing control between three converter cells inside each cluster, paying attention to the $n^{\text {th }}$-converter cells.

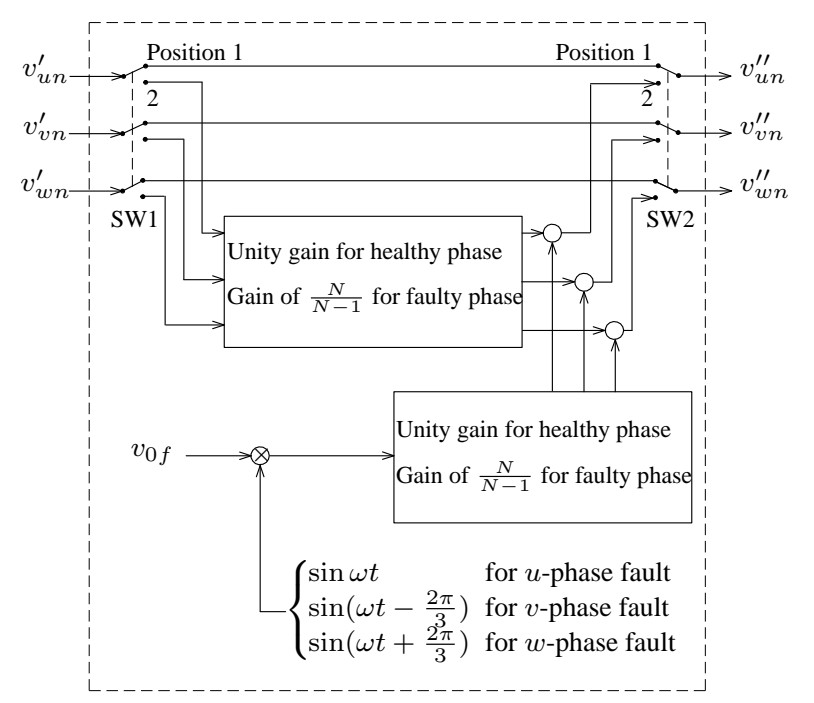

Fig. 8. Block diagram of the fault-tolerant control riding through a single-converter-cell fault.

unit in the $u$-cluster. The superimposed ac voltage to minimize the difference is determined as

$$
v_{\text {Bun }}=\sqrt{2} \cdot K_{1} \cdot \Delta \mathrm{SOC}_{u n} \cdot \sin (\omega t+\delta),
$$

where $K_{1}$ is a proportional gain. Unity power-factor operation makes the power-factor angle $\delta$ equal to zero for charging operation, or equal to $\pi$ for discharging operation. The individual SOC-balancing control does not interfere with the active-power control and the clustered SOC-balancing control because the sum of superimposed voltages in a cluster is equal to zero.

\section{FAULT-TOLERANT CONTROL}

Figure 8 describes the detailed block diagram of the faulttolerant control shown in Figure 5, considering a singleconverter-cell fault. During normal operation, switches SW1 and SW2 are closed at position 1. When the converter-cell fault occurs, the switches move to position 2, enabling the fault-tolerant control. Similar to the clustered SOC-balancing control, the core of this control is also the injection of the zerosequence voltage at the fundamental or line frequency.

For simplicity, the ac voltages of the $n$-th converter cells in 
the three clusters for normal operation can be represented as

$$
\begin{aligned}
& v_{u n}=m v_{D C} \sin \omega t \\
& v_{v n}=m v_{D C} \sin \left(\omega t-\frac{2 \pi}{3}\right) \\
& v_{w n}=m v_{D C} \sin \left(\omega t+\frac{2 \pi}{3}\right),
\end{aligned}
$$

where $m$ is the modulation index, and $n=1,2, \cdots N$.

If the $u$-phase converter cell numbered 1 is out of order, it is bypassed.

$$
v_{u 1}=0 .
$$

The modulation index $m$ of the $N-1$ heathy converter cells in the $u$-phase is increased by a factor of $N /(N=1)$ to achieve a three-phase balanced line-to-line ac voltage and the neutral shift is executed to achieve SOC balancing of the $3 N-1$ healthy battery units. The neutral shift is based on the injection of line-frequency zero-sequence voltage which is out of phase by $180^{\circ}$ with the $u$-phase voltage where a single-converter-cell fault occurs.

The ac voltages of the healthy converter cells can then be expressed as

$$
\begin{aligned}
& v_{u n}=\frac{N}{N-1} m v_{D C} \sin \omega t-\frac{N}{N-1} v_{0 f} \sin \omega t \\
& v_{v n}=m v_{D C} \sin \left(\omega t-\frac{2 \pi}{3}\right)-v_{0 f} \sin \omega t \\
& v_{w n}=m v_{D C} \sin \left(\omega t+\frac{2 \pi}{3}\right)-v_{0 f} \sin \omega t .
\end{aligned}
$$

where $n=2,3, \cdots N$ for the $u$-phase, while $n=1,2, \cdots N$ for the $v$-and $w$-phases.

The energy-balancing constraint that all the $3 N-1$ powers absorbed by the healthy battery units should be equal to each other can derive the following equation,

$$
v_{0 f}=\frac{2}{3 N-1} m v_{D C} .
$$

This indicates that injecting the zero-sequence voltage given by (19), as well as being out of phase by $180^{\circ}$ with the $u$-phase voltage, makes all the $3 N-1$ powers equal, thus balancing the $3 N-1$ SOC values in spite of a single faulty converter cell in the $u$-phase.

\section{EXPERIMENTAL RESULTS DURING NORMAL OPERATION}

\section{A. Startup Waveforms}

The battery energy storage system requires no external startup circuit. The startup procedure is similar to the one presented in [32]. Figure 3 includes a simple startup circuit, consisting of two sub-circuits:

- ac startup circuit consisting of the three-phase circuit breaker $\mathrm{CB} 1$, the three-phase magnetic contactor MC1, and the current-limiting resistor $R_{1}$ in each phase, and

- dc startup circuit consisting of the circuit breaker CB2, the magnetic contactor $\mathrm{MC} 2$, and the current limiting resistor $R_{2}$ in each converter cell.

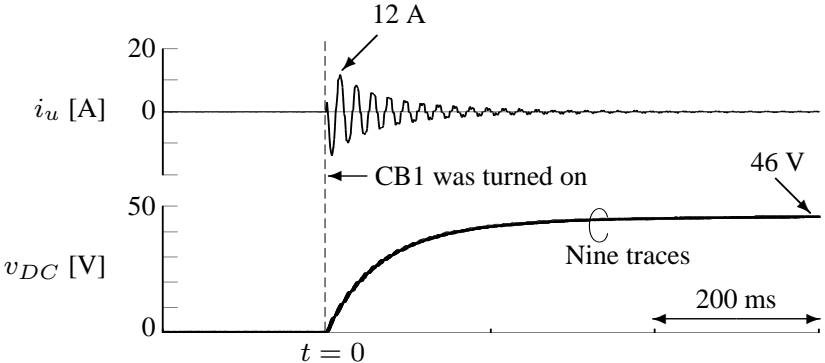

(a)

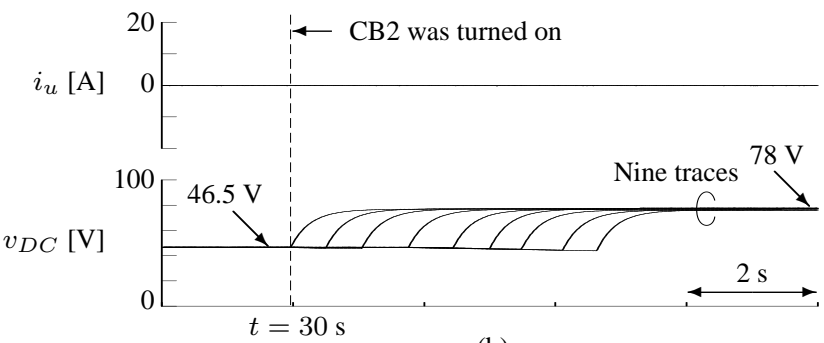

(b)

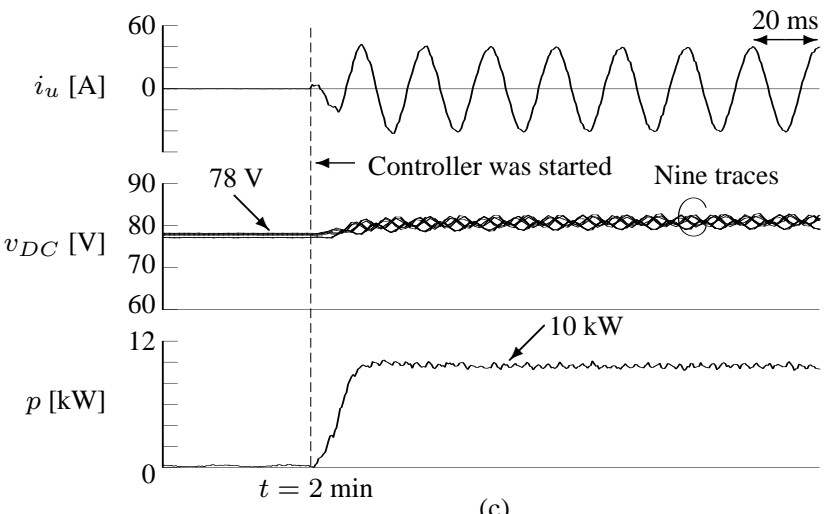

(c)

Fig. 9. Experimental waveforms when the battery energy storage system was started. (a) CB1 was turned on at $t=0$, (b) CB2 was turned on at $t=30 \mathrm{~s}$, and (c) Controller was started at $t=2 \mathrm{~min}$.
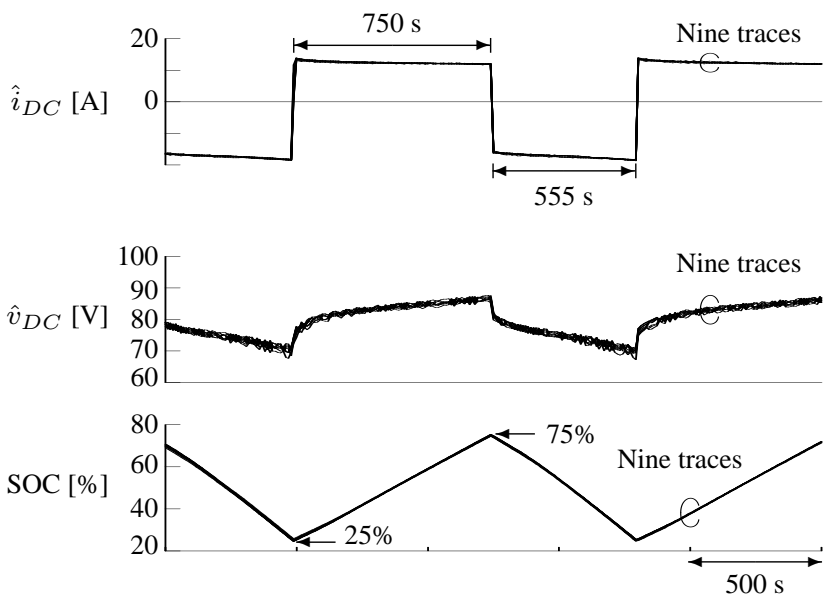

Fig. 10. Experimental waveforms with repetitive charging and discharging of the energy storage system, where a mean SOC window was kept between 25 and $75 \%$.

Figure 9 shows the waveforms during startup. At time $t=0, \mathrm{CB} 1$ was switched on, whereas $\mathrm{MC} 1$ as well as $\mathrm{CB} 2$ and MC2 in each converter cell remained switched off. Each of the nine capacitors started charging through $R_{1}$ and the respective converter cell operating as a diode rectifier. The 

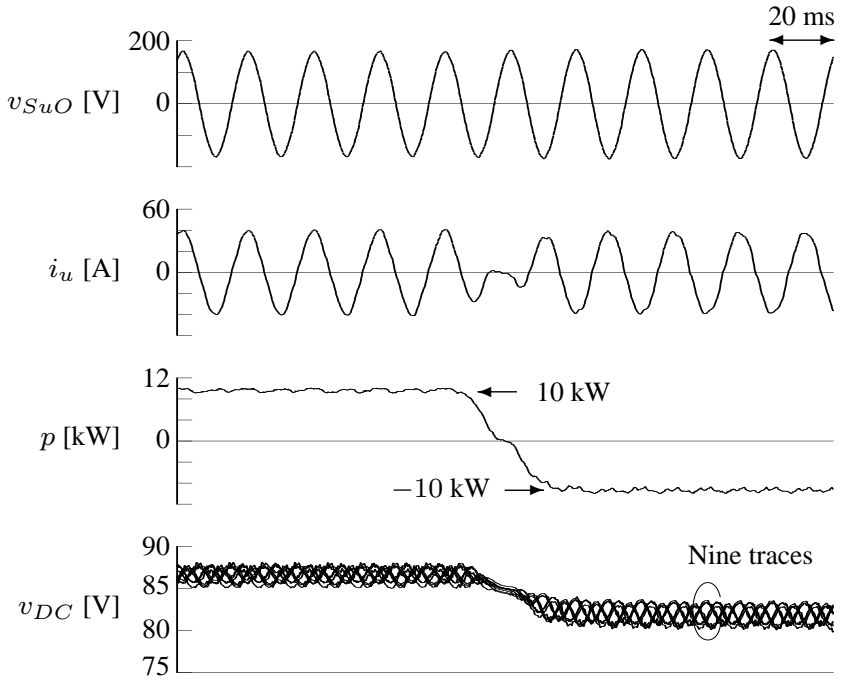

Fig. 11. Experimental waveforms when $p^{*}$ was changed from $10 \mathrm{~kW}$ to $-10 \mathrm{~kW}$ in $30 \mathrm{~ms}$ with a mean SOC value of $70 \%$.
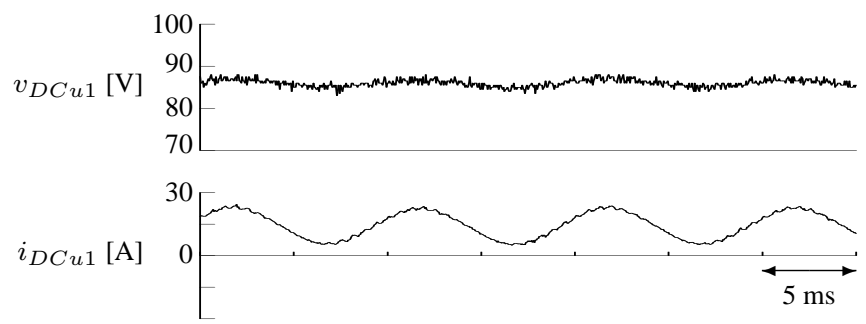

Fig. 12. Battery-unit voltage and current waveforms during charging at $10 \mathrm{~kW}$ with a mean SOC value of $65 \%$.

inrush ac current was limited to $12 \mathrm{~A}$ (peak), which was below the rated current of $30 \mathrm{~A}$. At the time of $t=30 \mathrm{~s}$, when the starting ac current decayed to zero, the MC1 as well as nine CB2's were turned on sequentially. The dc-link voltages then reached the battery-unit voltages of $78 \mathrm{~V}$, as shown in Figure 9(b). The nine starting resistors $R_{2}$ limit the inrush dc currents when the nine battery units are connected to the dc links and are bypassed by the nine magnetic contactors MC2 in $5 \mathrm{~s}$. At $t=2 \mathrm{~min}$, the controller was started and the gate signals were provided to the nine converter cells, along with the active-power command $p^{*}$. The system thus came to normal operation.

\section{B. Charging and Discharging Waveforms}

Figure 10 shows the experimental waveforms when the energy storage system was repetitively charged up to a mean SOC value of $75 \%$ and discharged down to a mean SOC value of $25 \%$. Although the experiment used a mean SOC window between $25 \%$ and $75 \%$, a wider window, for example, from $10 \%$ to $90 \%$, may be used in an actual system with more precise estimation of SOC. However, NiMH batteries show extended cycle life with a lower depth-of-discharge (DOD)* value [20]. Here, $\hat{i}_{D C}, \hat{v}_{D C}$, and SOC were obtained from a BMS with a sampling rate of $1 \mathrm{~s}^{-1}$. Since the power was set at

\footnotetext{
*The term "DOD" is a measure of energy withdrawn from a battery, expressed as a percentage of the full capacity.
}

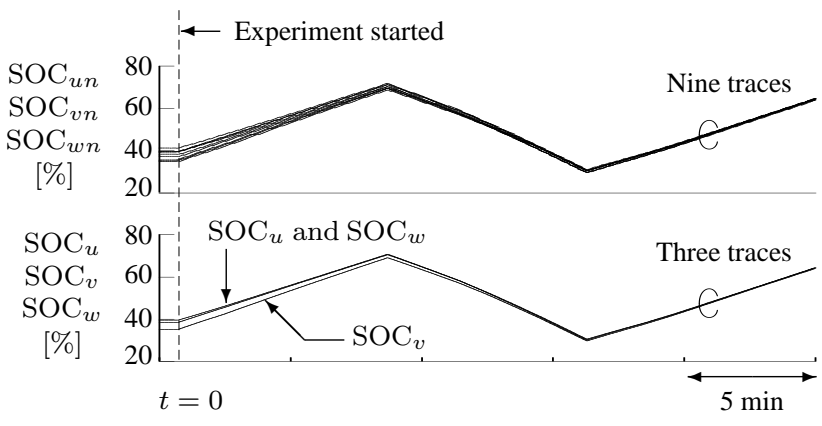

Fig. 13. Experimental waveforms to verify the effectiveness of the SOC-balancing control, where a mean SOC value was kept between 30 and $70 \%$ with $p^{*}=10 \mathrm{~kW}$ and $q^{*}=0$.

$p= \pm 10 \mathrm{~kW}$, the charging or discharging battery-unit current was observed to be around $15 \mathrm{~A}$. This is equivalent to a C-rate ${ }^{\dagger}$ of $2.7 \mathrm{C}(=15 \mathrm{~A} / 5.5 \mathrm{Ah})$.

Figure 11 shows experimental waveforms from charging to discharging operation with a ramp change in active power from $10 \mathrm{~kW}$ to $-10 \mathrm{~kW}$ in $30 \mathrm{~ms}$ with a mean SOC value around $70 \%$. The waveforms of $v_{S u O}$ and $i_{u}$ were in phase during charging, while they were out of phase by $180^{\circ}$ during discharging, because this system was operated with a condition of $q^{*}=0$. Note that the battery-unit dc voltages changed from $87 \mathrm{~V}$ to $82 \mathrm{~V}$ as soon as the power command $p^{*}$ was changed from $+10 \mathrm{~kW}$ to $-10 \mathrm{~kW}$. This voltage difference resulted from a voltage across an equivalent series resistance existing in the individual battery units.

\section{Battery-Unit Voltage and Current Waveforms}

Figure 12 shows the voltage and current waveforms of a battery unit in the $u$-cluster during charging at $10 \mathrm{~kW}$ with a mean SOC value of $65 \%$. The waveform of $v_{D C u 1}$ contained a $100-\mathrm{Hz}$ component of $2 \mathrm{~V}$ (peak-to-peak), and the waveform of $i_{D C u 1}$ contained a $100-\mathrm{Hz}$ component of 17.5 A (peak-to-peak). They are in phase so that the equivalent series impedance of the battery-unit can be considered purely resistive. The equivalent series resistance is estimated to be $115 \mathrm{~m} \Omega(=2 \mathrm{~V} / 17.5 \mathrm{~A})$. The resistance of a standalone battery unit was measured to be $133 \mathrm{~m} \Omega$ at an SOC value of $65 \%$ and a battery temperature of $30^{\circ} \mathrm{C}$.

\section{Effectiveness of the SOC-Balancing Control}

In Figure 13, the upper part shows the nine SOC values of the battery units, while the lower part shows the three mean SOC values of the $u$-, $v$ - and $w$-clusters. Before starting the experiment $(t=0)$, the SOC values of the nine battery units had a maximal imbalance of $5 \%$ between the lowest and highest ones. However, when the SOC-balancing control was started along with $p^{*}= \pm 10 \mathrm{~kW}$ at $t=0$, the nine SOC values gradually started converging together. In about 15 mins, all the SOC values became equal. This verified the effectiveness of the SOC-balancing control.

†The term "C-rate" is a charging or discharging rate of a battery expressed in terms of its total storage capacity in $\mathrm{Ah}$. A rate of $1 \mathrm{C}$ means a complete transfer of the stored energy in $1 \mathrm{~h}$. 


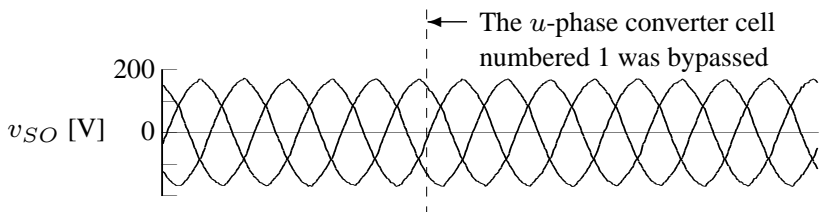

$i[\mathrm{~A}$

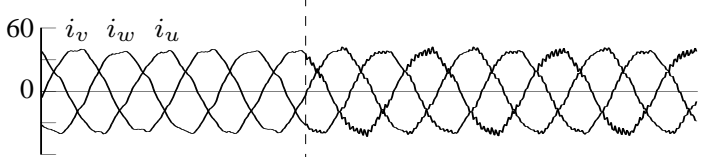

$v_{D C}[\mathrm{~V}$

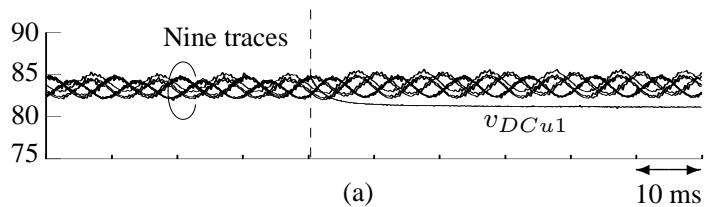

(a)

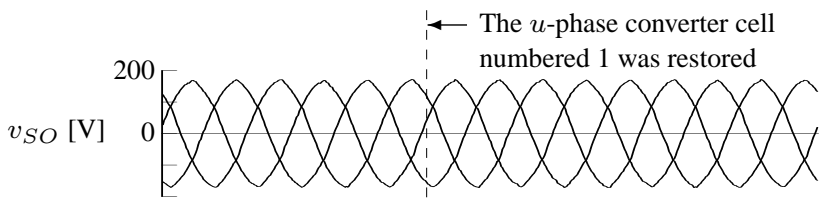

$i[\mathrm{~A}]$

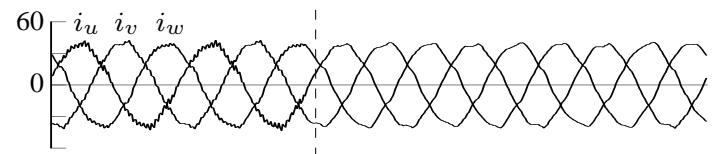

$v_{D C}[\mathrm{~V}$

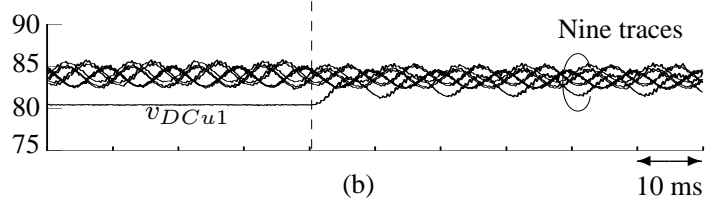

Fig. 14. Experimental waveforms during charging at $10 \mathrm{~kW}$. (a) when the $u$-phase converter cell numbered 1 was bypassed with a mean SOC value of $67 \%$, and (b) when the $u$-phase converter cell

numbered 1 was restored with a mean SOC value of $69 \%$.

\section{EXPERIMENTAL RESULTS DURING FAULT-TOLERANT OPERATION}

\section{A. Converter-Cell Bypass and Restore}

Figure 14 shows experimental waveforms during faulttolerant operation. Figure 14(a) shows those during charging before and after the $u$-phase converter cell numbered 1 was bypassed. The converter cell was bypassed by turning on the two upper IGBTs and turning off the two lower IGBTs. The remaining eight battery units were kept charging at $10 \mathrm{~kW}$ with a mean SOC value of $67 \%$. Losing the converter cell in the $u$-phase brought an increase in switching ripples to the line currents $i_{u}, i_{v}$, and $i_{w}$.

Figure 14(b) shows experimental waveforms during charging before and after the $u$-phase converter cell was restored to the normal operation. The mean SOC value was $69 \%$. These waveforms verify smooth transition from the normal operation to the fault-tolerant operation, and vice versa. Generally, the fault-tolerant operation would last for a short period of time until the faulty converter cell is repaired.

\section{B. Converter-Cell Voltages}

Figure 15 shows various voltage waveforms at the ac side of the cascade converter during normal discharging operation, while Figure 16 shows those during fault-tolerant operation both at the rated power of $10 \mathrm{~kW}$. The three $u$-phase convertercell ac voltages $\left(v_{u 1}, v_{u 2}\right.$ and $\left.v_{u 3}\right)$ and one $v$-phase convertercell ac voltage $\left(v_{v 1}\right)$ were picked up as representatives. These as well as the other five ac converter-cell voltages $\left(v_{v 2}, v_{v 3}, \cdots\right.$, and $\left.v_{w 3}\right)$ were three-level waveforms during normal operation. Note that the ac voltage $v_{u 1}$ was zero in Figure 16(a). The three line-to-neutral voltages were sevenlevel waveforms in the normal operation, whereas the $u$-phase voltage was degraded to a five-level waveform in the faulttolerant operation. Although the fundamental components of the line-to-neutral voltages are not balanced, those of the lineto-line voltages $v_{u v}, v_{v w}$, and $v_{w u}$ in Figure 16(c) are well balanced.

\section{SOC Balancing During Fault-Tolerant Operation}

Figure 17 shows SOC waveforms during fault-tolerant operation. Initially, all the nine battery units were operating at $10 \mathrm{~kW}$ with a mean SOC window between 50 and $70 \%$. At $t=0$, the $u$-phase converter cell numbered 1 was bypassed and the fault-tolerant control was enabled. The remaining eight converter cells were repetitively charged and discharged at $10 \mathrm{~kW}$. It is clear from the waveforms that the fault-tolerant control is effective in balancing the SOC values of all the $3 N-1(=8)$ healthy battery units during a converter-cell fault.

\section{CONCLUSION}

This paper has described a battery energy storage system based on a three-phase cascade PWM converter, with focus on control methods for SOC balancing of multiple battery units and fault-tolerant operation. Experimental results obtained from a $200-\mathrm{V}, 10-\mathrm{kW}, 3.6-\mathrm{kWh}$ laboratory model have verified the effectiveness of the proposed control methods.

\section{REFERENCES}

[1] S. R. Bull. Renewable energy today and tomorrow. Proceedings of the IEEE, 89(8):1216-1226, August 2001.

[2] Global Wind 2008 Report. Global Wind Energy Council, 2009.

[3] R. D. Richardson and G. M. McNerney. Wind energy systems. Proceedings of the IEEE, 81(3):378-389, March 1993.

[4] P. F. Ribeiro, B. K. Johnson, M. L. Crow, A. Arsoy, and Y. Liu. Energy storage systems for advanced power applications. Proceedings of the IEEE, 89(12):17441756, December 2001.

[5] L. H. Walker. 10-mw gto converter for battery peaking service. IEEE Transactions on Industry Applications, 26(1):63-72, January/February 1990.

[6] N. W. Miller, R. S. Zrebiec, R. W. Delmerico, and G. Hunt. Design and commissioning of a 5-mva, 2.5-mwh battery energy storage. In Proc. of IEEE Transmission and Distribution Conference, pages 339345, September 1996.

[7] R. H. Baker and L. H. Bannister. Electric power converter. U.S. Patent 3867643, February 1975. 

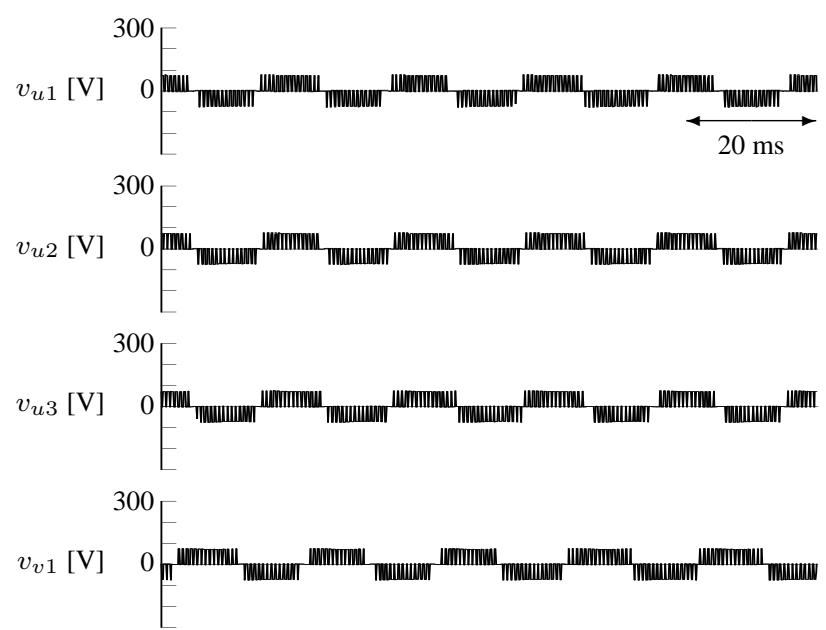

(a)
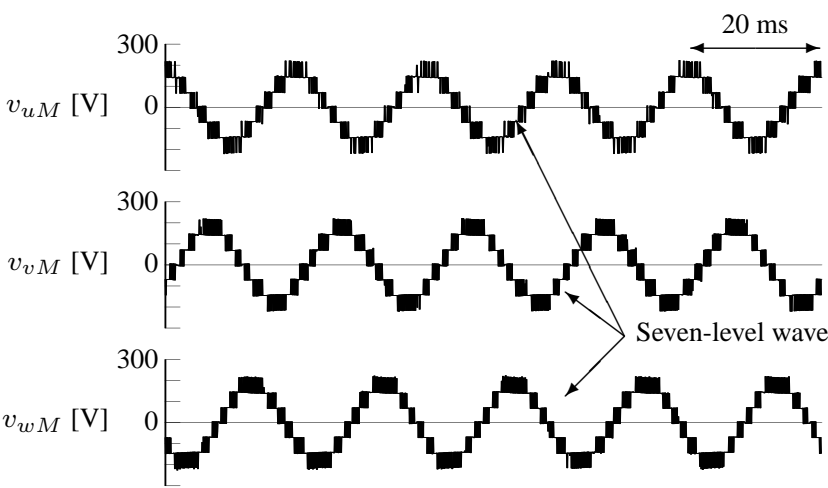

(b)
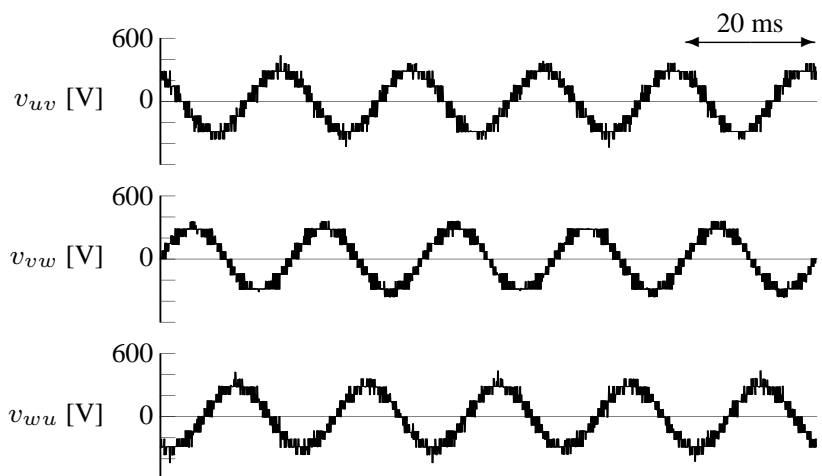

(c)

Fig. 15. Experimental voltage waveforms at the ac side of the cascade converter during normal operation at $10 \mathrm{~kW}$ in discharging. (a) four converter-cell ac voltages, (b) three line-to-neutral voltages, and (c) three line-to-line voltages.

[8] R. H. Baker. Bridge converter circuit. U.S. Patent 4270163, May 1981.

[9] A. Nabae, I. Takahashi, and H. Akagi. A new neutralpoint-clamped pwm inverter. IEEE Transactions on Industry Applications, IA-17(5):518-523, September/October 1981.

[10] M. Marchesoni, M. Mazzucchelli, and S. Tenconi. A nonconventional power converter for plasma stabilization. IEEE Transactions on Power Electronics, 5(5):212-219, April 1990.

[11] T. A. Meynard and H. Foch. Multi-level conversion: high voltage choppers and voltage-source inverters. In Proc. of IEEE PESC, volume 1, pages 397-403, 1992.
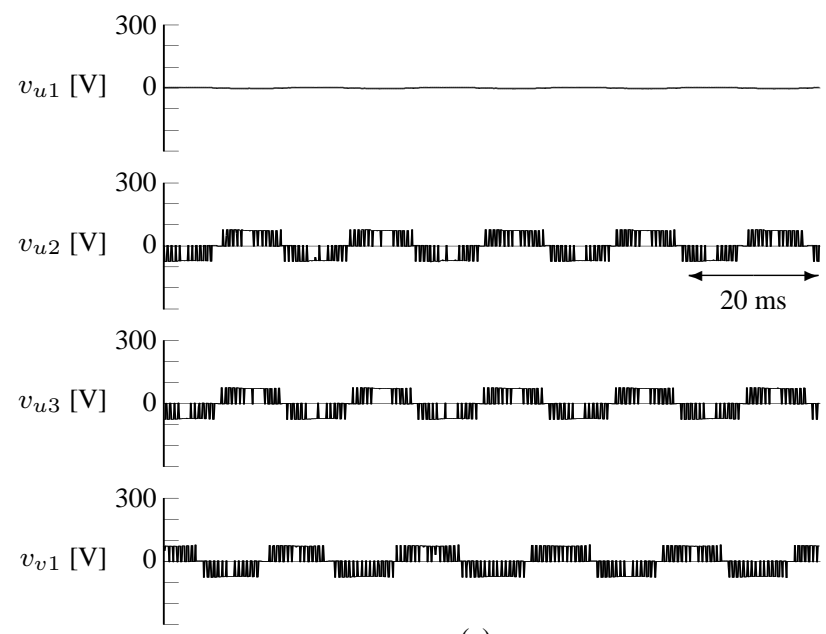

(a)
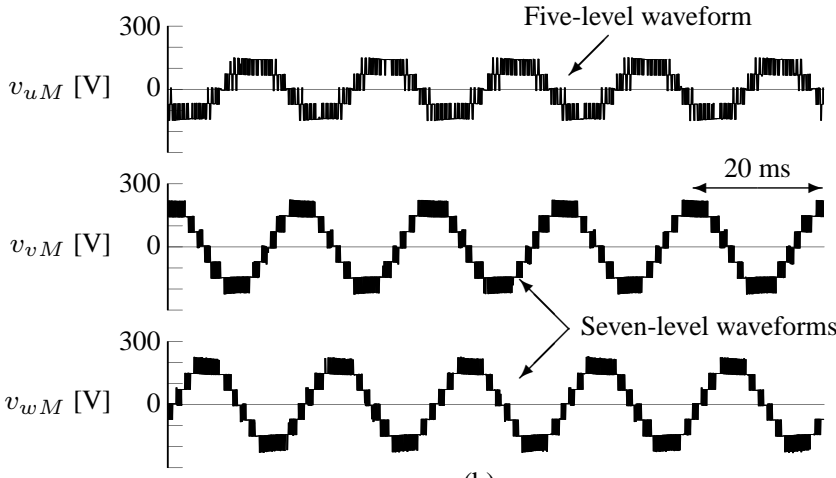

(b)
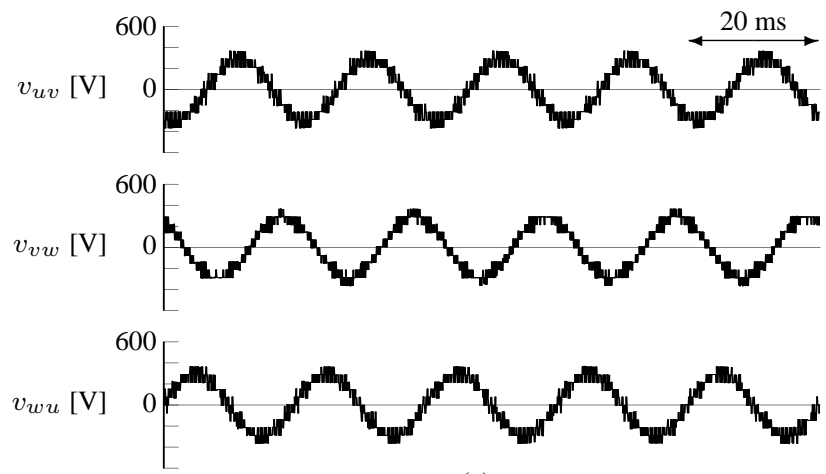

(c)

Fig. 16. Experimental voltage waveforms at the ac side of the cascade converter during fault-tolerant operation at $10 \mathrm{~kW}$ in discharging. (a) four converter-cell ac voltages, (b) three line-to-neutral voltages, and (c) three line-to-line voltages.

[12] F. Z. Peng and J. S. Lai. Multilevel cascade voltagesource inverter with separate dc sources. U.S. Patent 5642275, June 1997.

[13] F. Z. Peng, J. S. Lai, J. W. McKeever, and J. VanCoevering. A multilevel voltage-source inverter with separate dc sources for static var generation. IEEE Transactions on Industry Applications, 32(5):11301138, September/October 1996.

[14] P. W. Hammond. A new approach to enhance power quality for medium voltage ac drives. IEEE Transactions on Industry Applications, 33(1):202-208, January/February 1997.

[15] J. D. Ainsworth, M. Davies, P. J. Fitz, K. E. Owen, and 


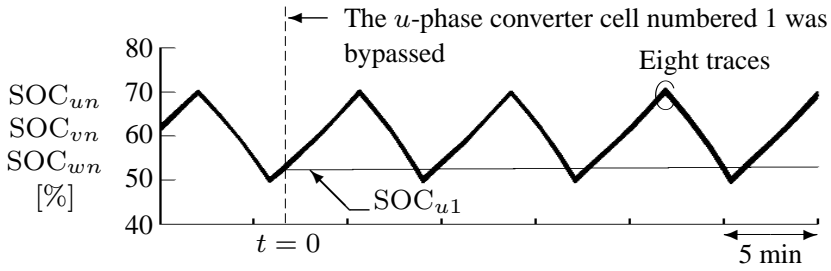

Fig. 17. Experimental SOC waveforms with the fault-tolerant control, when the $u$-phase converter cell numbered 1 was bypassed while the remaining eight battery units were repetitively charged and discharged at $10 \mathrm{~kW}$.

D. R. Trainer. Static var compensator (statcom) based on single phase chain circuit converters. IEE Proceedings Generation, Transmission and Distribution, 145(4):381386, July 1998.

[16] R. H. Osman. A medium-voltage drive utilizing seriescell multilevel topology for outstanding power quality. In Proc. of IEEE IAS Annual Meeting, volume 4, pages 2662-2669, October 1999.

[17] J. Dixon, L. Morgan, J. Rodriquez, and R. Domke. Reactive power compensation technologies: state-of-theart review. Proceedings of the IEEE, 93(12):2144-2164, December 2005.

[18] H. Akagi, S. Inoue, and T. Yoshii. Control and performance of a transformerless cascade pwm statcom with star configuration. IEEE Transactions on Industry Applications, 43(4):1041-1049, July/August 2007.

[19] A. Burke. Ultracapacitors: why, how, and where is the technology. Journal of Power Sources, 91(1):37-50, November 2000.

[20] U. Kohler, J. Kumpers, and M. Ullrich. High performance nickel-metal hydride and lithium-ion batteries. Journal of Power Sources, 105(2):139-144, March 2002.

[21] J. M. Carrasco, L. G. Franquelo, J. T. Bialasiewicz, R. C. PortilloGuisado, M. A. M. Prats, J. I. Leon, and N. Moreno-Alfonso. Power-electronic systems for the grid integration of renewable energy sources: a survey. IEEE Transactions on Industrial Electronics, 53(4):1002-1016, June 2006.

[22] L. M. Tolbert, F. Z. Peng, and T. G. Habetler. Multilevel converters for large electric drives. IEEE Transactions on Industry Applications, 35(1):36-44, January/February 1999.

[23] P. Wikstrom, L. A. Terens, and H. Kobi. Reliability, availability, and maintainability of high-power variablespeed drive systems. IEEE Transactions on Industry Applications, 36(1):231-241, January/February 2000.

[24] F. A. DeWinter, R. Paes, R. Vermaas, and C. Gilks. Maximizing large drive availability. IEEE Industry Applications Magazine, 8(4):66-75, July/August 2002.

[25] W. Song and A. Q. Huang. Control strategy for faulttolerant cascaded multilevel converter based statcom. In Proc. of IEEE APEC, pages 1073-1076, February/March 2007.
[26] S. Wei, B. Wu, F. Li, and X. Sun. Control method for cascaded h-brige multilevel inverter with faulty power cells. In Proc. of IEEE APEC, volume 1, pages 261-267, February 2003.

[27] J. Rodriguez, P. W. Hammond, J. Pontt, R. Musalem, P. Lezana, and M. J. Escobar. Operation of a mediumvoltage drive under faulty conditions. IEEE Transactions on Industrial Electronics, 52(4):1080-1085, August 2005.

[28] P. Lezana, G. Ortiz, and J. Rodriguez. Operation of regenerative cascade multicell converter under fault condition. In Proc. of IEEE COMPEL, volume 1, pages $1-6$, August 2008.

[29] J. Rodriguez, J. S. Lai, , and F. Z. Peng. Multilevel inverters: a survey of topologies, controls, and applications. IEEE Transactions on Industrial Electronics, 49(4):724-738, August 2002.

[30] J. J. C. Kopera. Inside the Nickel metal hydride battery. Cobasys, June 2004.

[31] C. C. Chan. The state of the art of elctric, hybrid, and fuel cell vehicles. Proceedings of the IEEE, 95(4):704718, April 2007.

[32] Y. Liang and C. O. Nwankpa. A new type of statcom based on cascading voltage-source inverters with phaseshifted unipolar spwm. IEEE Transactions on Industry Applications, 35(5):1118-1123, September/October 1999.

[33] D. G. Holmes and B. P. McGrath. Opportunities for harmonic cancellation with carrier-based pwm for two-level and multilevel cascaded inverters. IEEE Transactions on Industry Applications, 37(2):574-582, March/April 2001.

[34] P. C. Loh, D. G. Holmes, and T. A. Lipo. Implementation and control of distributed pwm cascaded multilevel inverters with minimal harmonic distortion and commonmode voltage. IEEE Transactions on Power Electronics, 20(1):90-99, January 2005.

[35] S. T. Hung, D. C. Hopkins, and C. R. Mosling. Extension of battery life via charge equalization control. IEEE Transactions on Industrial Electronics, 40(1):96-104, February 1993.

[36] N. H. Kutkut, D. M. Divan, and D. W. Novotny. Charge equalization for series connected battery strings. IEEE Transactions on Industry Applications, 31(3):562-568, May/June 1995.

[37] K. Nishijima, H. Sakamoto, and K. Harada. A pwm controlled simple and high performance battery balancing system. In Proc. of IEEE PESC, volume 1, pages 517-520, 2000.

[38] S. Piller, M. Perrin, and A. Jossen. Methods for state-ofcharge determination and their applications. Journal of Power Sources, 96(1):113-120, June 2001.

[39] L. Maharjan, T. Yoshii, S. Inoue, and H. Akagi. A transformerless energy storage system based on a cascade pwm converter with star configuration. IEEE Transactions on Industry Applications, 44(5):16211630, September/October 2008.

[40] R. E. Betz, T. Summers, and T. Furney. Symmetry 
compensation using a h-bridge multilevel statcom with zero sequence injection. In Proc. of IEEE IAS Annual Meeting, pages 1724-1731, October 2006.

\section{BIOGRAPHIES}

Hirofumi Akagi was born in Okayama, Japan, on August 19 , 1951. He received the B.S. degree from Nagoya Institute of Technology, Nagoya, Japan, in 1974, and the M.S. and Ph.D. degrees from Tokyo Institute of Technology, Tokyo, Japan, in 1976 and 1979, respectively, all in electrical engineering.

During 1979, he was an Assistant Professor with Nagaoka University of Technology, Nagaoka, where he later became an Associate Professor in the Department of Electrical Engineering. For a period of ten months during 1987, he was a Visiting Scientist at Massachusetts Institute of Technology (MIT), Cambridge, where he was also a Visiting Professor from June to August in 1996. From 1991 to 1999, he was a Professor in the Department of Electrical Engineering, Okayama University, Okayama. From March to May 1996, he was a Visiting Professor at the University of Wisconsin, Madison. Since January 2000, he has been a Professor in the Department of Electrical and Electronic Engineering, Tokyo Institute of Technology. He has been a keynote or an invited speaker at international conferences. He has authored or coauthored more than 80 IEEE TRANSACTIONS papers, and two invited papers published in the PROCEEDINGS OF THE IEEE. The total citation index for his papers in Google Scholar is more than 7000. His current research interests include power conversion systems, ac motor drives, active and passive electromagnetic interference (EMI) filters, high-frequency resonant inverters for induction heating and corona discharge treatment processes, and utility applications of power electronics such as active filters, self-commutated back-to-back (BTB) systems, and flexible ac transmission system (FACTS) devices.

Dr. Akagi was elected as a Distinguished Lecturer of the IEEE Power Electronics Society and the IEEE Industry Applications Society for 1998-1999. He received two IEEE Transactions on Industry Applications Prize Paper Awards in 1991 and 2004, two IEEE Transactions on Power Electronics Prize Paper Awards in 1999 and 2003, nine IEEE Industry Applications Society Committee Prize Paper Awards, the 2001 IEEE William E. Newell Power Electronics Award, the 2004 IEEE Industry Applications Society Outstanding Achievement Award, and the 2008 IEEE Richard H. Kaufmann Technical Field Award. He served as the President of the IEEE PELS for 2007-2008.

Laxman Maharjan was born in Lalitpur, Nepal, on January 2, 1979. He received the B.E. degree in Electrical Engineering from Tribhuvan University, Institute of Engineering, Lalitpur, Nepal, in 2002. He was a research student in Tokyo Institute of Technology, Tokyo, Japan, from October 2004 to March 2005. He received the M.S. degree in Electrical and Electronic Engineering from Tokyo Institute of Technology in 2007. Since 2007, he has been working toward the Ph.D. degree in the same university.

His research interests include cascade multilevel converters and energy storage systems. 